\title{
Ensaio sobre a memória anarquista: a história como ficção coletiva*
}

\author{
Edgar Salvadori de Decca* *
}

Para Jaime Cuberos, in memorian

Algumas vezes as COISAS ACONTECEM de uma maneira que vai muito além de nossas expectativas. Viajar para Barcelona me parecia uma decisão bastante importante, afinal lá iria se realizar uma exposição internacional do anarquismo. Nenhum outro lugar poderia fundir o passado e o presente com tamanha intensidade. Para mim, seria como reviver em pleno outono europeu "o curto verão da anarquia", escavando na memória de antigos militantes anarquistas uma experiência vivida ali, com a expectativa de que eles pudessem identificar espaços, retraçar trajetórias, reconstituindo em suas nuances um tempo carregado de promessas. Barcelona, por si só, era inspiradora. Afinal, muitos dos velhos anarquistas haviam estado lá durante a Guerra Civil espanhola, e outros tantos militantes impregnavam de memórias as ruas e os surpreendentes recantos da cidade.

Interessante observar que estas divagações me ocorreram ainda no aeroporto de Cumbica, antes de meu embarque, deixando-me perplexo, pois perguntava a mim mesmo: quais eram realmente os objetivos de minha viagem? Afinal, o que você espera encontrar nesta exposição internacional do anarquismo? Ainda fiel ao meu roteiro inicial, respondi que eu iria observar e analisar as tendências do anarquismo contemporâneo para entender de que maneira esta doutrina da ação individual e coletiva seria capaz de se posicionar frente à falência das utopias elaboradas pela modernidade do século XIX. Tinha como questão referencial o fato de que não só o marxismo passava por uma profunda crise, mas também outras correntes do socialismo novecentista, dentre elas, sem dúvi-

\footnotetext{
* Este texto, relativamente modificado, foi feito originalmente para ser o primeiro capítulo de um livro sobre a memória do anarquismo, que, um dia, pretendo terminar. (Recebido para publicação em setembro de 1998.)

** Historiador da Unicamp.
} 
da, o anarquismo. Contudo, não podia deixar de considerar que o anarquismo se comprometeu menos que o marxismo, enquanto doutrina de classe. Afinal, os problemas de identidade de classe e de suas correspondências com determinadas doutrinas políticas de cunho socialista só faziam sentido, durante a exposição, para a vertente anarco-sindicalista e somente para ela. Aliás, esta tensão permeou toda a Exposição de Barcelona e, por sinal, permaneceu pendente: como conciliar um anarquismo libertário e individualista com as correntes classistas do anarco-sindicalismo?

Mas acho que estou me adiantando um pouco. Evidentemente, fui para Barcelona esperando encontrar na doutrina anarquista as respostas para as questões atuais de autonomia individual, da crise do Estado e da falência de doutrinas políticas elaboradas sobre o suporte de classe e inspiradas por ideais liberais ou socialistas. Contudo, a minha participação na exposição internacional iria se dar pela apresentação em uma mesa-redonda de meu projeto de pesquisa sobre as memórias anarquistas. Estaria na exposição menos como um militante anarquista e mais como um pesquisador das formas de pensamento e da irradiação das idéias libertárias. Para participar, na condição de observador, de uma exposição anarquista, a indicação feita pelos militantes brasileiros foi decisiva, além de facilitar o acesso a várias personagens importantes do pensamento e ação libertários.

Quando cheguei ao moderníssimo aeroporto de Barcelona, minha cabeça ainda rodava frente às possibilidades que eu desejava encontrar na exposição. A primeira providência foi procurar a direção correta da casa de Verena Stolcke, uma antropóloga muito conhecida entre nós, responsável pela formação do grupo de antropologia da Unicamp. Ela havia me oferecido hospedagem e eu estava muito ansioso para encontrá-la, esperando que ela me orientasse na pesquisa, principalmente, por ela ter convivência com os grupos anarquistas de Barcelona.

Verena mora a trinta minutos do centro de Barcelona, em uma pequena cidade chamada Cerdanyola del Valles, servida por um excelente metrô. A localidade é um verdadeiro sonho; pequena, com estreitas vielas e um comércio de lojinhas que, aos nossos olhos acostumados com os shopping-centers, desconcerta ao ponto de não sabermos nos movimentar adequadamente. Tudo é muito pessoal e aconchegante, criando um espaço de incrível familiaridade. O encontro com Verena foi muito afetivo. Desde logo, ela se colocou à disposição, dando muitas pistas para a minha pesquisa. Depois de uma longa conversa acompanhada de excelente vinho espanhol e queijos, eu já havia decidido que meu trabalho durante a exposição seria o de entrevistar as personalidades mais destacadas do anarquismo. Afinal, a ocasião era uma oportunidade rara, onde estariam presentes figuras significativas da história do anarquismo. Fiquei eufórico com a idéia. Poderia me envolver em um trabalho com as memórias anarquistas, justamente em Barcelona, cidade-símbolo da experiência 
libertária. Eu iria me encontrar com algumas personagens que eram o próprio suporte das memórias anarquistas no cenário internacional.

Depois de me recuperar da noite perdida no vôo entre São Paulo e Barcelona, acordei e me dirigi ao Centro Cívico, espaço onde estava acontecendo a exposição internacional. As primeiras pessoas que encontrei foram Rudolf de Jong, exdiretor do Arquivo do Instituto Internacional de História Social de Amsterdã, e Marianne Anckel, atual diretora do CIRA, centro de documentação anarquista de Lausanne, Suíça. Eles também estavam preocupados com a questão das memórias anarquistas, pois eram responsáveis por arquivos que preservam os documentos existentes sobre a doutrina e as ações internacionais libertárias. Além deles, estavam presentes outros militantes que iriam discutir a preservação da memória do anarquismo na Espanha, Itália e também no Brasil. Entre muitos, estava Jaime Cuberos, a personagem mais importante do movimento anarquista de São Paulo.

Com as referências dadas por Verena, fui logo procurar os responsáveis pela organização da exposição internacional, para poder localizar melhor os participantes do evento. As informações foram muito promissoras. Na noite anterior, Verena havia me informado de que, provavelmente, o militante Diego Camacho estaria presente ao encontro. Ela mesma me animou a conseguir uma entrevista, a qualquer custo, pois Diego era, com certeza, uma das mais importantes personagens do anarquismo espanhol, dotado de uma memória prodigiosa. Meus pensamentos foram ficando cada vez mais claros. Estava diante de uma rara oportunidade para o trabalho com a memória, pois chegava à conclusão de que a geração ainda viva, hoje, teve como referência fundamental do anarquismo a experiência da guerra civil na Espanha. Assim como Diego, todos os velhos militantes presentes ao encontro deveriam ter na lembrança esse momento marcante da história do anarquismo.

Reconheço que, nos primeiros dias em Barcelona, senti inveja de Hans Magnus Ensensberger, por ele ser o autor do magnífico livro $O$ curto verão da anarquia. A imagem de seu trabalho se confundia com as minhas expectativas, porque ele também optou por uma experiência com a memória, levando em conta todas as suas implicações: seus erros, equívocos, omissões, falhas e desvios, tomando como referência a personagem de Durruti e sua coluna durante a guerra civil na Espanha.

Como disse, logo na chegada, encontrei-me com Rudolf de Jong que, por sorte, me apresentou Anna Le Bedeva, de Moscou. Para dizer a verdade, quase perdi a respiração. Estava diante de uma adepta das idéias anarquistas que vivia na Rússia. Rudolf se afastou de nós para participar de uma reunião sobre arquivos anarquistas e pudemos nos conhecer melhor. Anna reservaria uma surpresa, ainda maior, para mim. Segundo me contou, seu interesse pelo anarquismo era devido às suas relações familiares, pois - disse-me com a maior naturalidade - era bisneta de Kropotkin e desde criança teve contato com as idéias do bisavô, através da corres- 
pondência pessoal dele, preservada pela família. Estava diante de uma possibilidade inusitada de conhecer os meios de preservação da memória no ambiente de uma família sob o regime soviético, sistema político que nunca teve muita simpatia pelos anarquistas. Marcamos uma entrevista para o dia seguinte e ao mesmo tempo pensei que, ao invés de fazer uma gravação programada de depoimento, deveria valorizar mais a informalidade das nossas conversas. Nestes momentos, nos damos conta da dificuldade do trabalho com a memória, pois ele exige, fundamentalmente, um espaço de familiaridade, afetividade e cumplicidade.

Esta dimensão do trabalho com a memória confirmou-se quando conheci Diego Camacho. Como Verena havia me adiantado, Diego era uma personagem singular, talvez única dentre aquelas da antiga geração dos anarquistas. Com 74 anos de idade, sua vitalidade é transbordante. Irreverente, sarcástico e licencioso, Diego cativa a todos. Desde a apresentação, sua figura transborda liberdade. Deixar-se envolver por ele é uma experiência maravilhosa. Largar-se pelas ruas de Barcelona, deixando que ele busque, por si mesmo, os espaços de sua memória, é simplesmente fascinante. Diego é, em si mesmo, aquele cruzamento que buscamos incessantemente, onde a memória individual se confunde com a memória coletiva. Poucas pessoas podem, como Diego, realizar esta fusão. Nele percebemos que a maneira de percorrer uma cidade, de se lembrar de um evento do passado, é mais do que uma experiência individual.

As correntes da memória coletiva atravessam Diego, sem que ele deixe de marcar a presença de sua memória individual. Parece um ponto jogado no infinito, um lugar quase inacessível, onde não se distingue passado, presente e futuro. Vivendo ao lado dele, julgamos possível visualizar as linhas indiscerníveis do perene e do eterno da memória. Diego representa este elo frágil da nossa existência limitada com a memória, que continuará existindo nos confins do tempo.

$\mathrm{Na}$ noite em que nos conhecemos, Diego me convidou para tomar um copo de vinho em um restaurante próximo ao local da exposição. Fiquei surpreso, não cabia na minha imaginação um encontro tão espontâneo. Juntou-se a nós seu filho, com a namorada. Além deles, uma jovem catalã, embasbacada por Diego, acompanhada por uma alemã, cuja cabeça estava em outro planeta, vivendo férias em Barcelona. O lado misterioso de Diego se revelou, ali mesmo, em torno de uma mesa de restaurante. Intrigava-me a relação que ele mantinha com o filho. Muito amistosa e afetiva, mas ao mesmo tempo enigmática. Riam muito, mas também deixavam um mistério pairando no ar. Seu filho? Estava se despedindo de Diego e de sua namorada. Partia para uma viagem, sem volta programada, para a Grécia.

Passava por mim um sentimento de que os verdadeiros libertários se despedem sem traumas. Compartilhavam com muito humor a experiência de abrigar, no apartamento onde viviam, seis jovens anarco-punks italianos, irreverentes e sem ne- 
nhuma grana para o próprio sustento. Nenhum gesto deixava entrever que a separação deles poderia ser muito prolongada. Riam Diego, seu filho e a namorada, que, por sinal, parecia muito apaixonada. Eu tinha a sensação de que na memória liberada dos ressentimentos e dos traumas, o tempo cronológico não tem existência. Que as despedidas não são quebras ou interrupções traumáticas de experiências comuns, mas promessas de novos reencontros. Se partir é dividir-se, sentir-se partido, dilacerado entre o que vai e o que fica, a memória é uma dimensão capaz de reconciliar este eu dividido, pois ela, quando livre, aponta permanências, outros possíveis de uma esperança que não tem mais fim, não tem mais fim, não tem mais fim... A memória livra o momento da partida de sua dimensão de evento irreversível.

Para o que vai e para o que fica o elo da memória desfaz o trauma da partida, mas isto só pode ser compreendido por pessoas que têm em comum uma profunda afetividade. Eu me dei conta desta dimensão da memória em um restaurante barcelonês, onde pai, filho e namorada se despediam afetuosamente.

Durante nossa conversa, Diego quis saber de minhas intenções. Disse-lhe que estava na exposição para conhecer melhor as memórias dos anarquistas. Interessava-me saber a distância que separava os eventos, que eram primeiramente vividos e que, posteriormente, acabavam por se transformar em eventos históricos. Dizia a ele que a História, do meu ponto de vista, institucionaliza uma versão do vivido, seqüestra da experiência do vivido os eventos, num trabalho completamente arbitrário. No limite, seria quase como dizer que o evento subtraído do vivido pela História estaria resguardado de qualquer renascimento ou acerto de contas. Submetido a uma ordem do sentido, o evento se apaziguaria e não mais incomodaria a nossa boa consciência. Estaria devidamente incorporado ao passado e à história. Não caberia mais revivê-lo, uma vez que a História já teria realizado o seu trabalho de controlar as suas possíveis insurgências inoportunas.

Apaziguar os eventos do passado, assim se constitui o trabalho da História, muito diferente da memória, que os reatualiza, exigindo que eles entrem, novamente, na experiência do vivido, se debatam e se confrontem com o nosso presente. Não se deveria autorizar que qualquer crime contra a humanidade fosse transformado em relato histórico, pois ali ele encontraria a sua justificativa. A História, em sua maneira de relatar o evento, paralisa-o no tempo - como dizem os historiadores: precisamos historicizá-lo - e a partir daí, ele tem uma data, uma circunstância, causas próximas ou remotas, sempre inteligíveis, sempre passíveis de julgamento, desde que estejam respeitados os cânones de que todo evento está aprisionado ao tempo em que ele aconteceu. Como perceber Diego fora das prisões que a História construiu, além das fronteiras do período, nas bordas do inefável, naquele ponto onde o acaso reverbera com toda a sua intensidade uma luz para o presente. 
Diego foi para mim essa experiência única com a memória. Um evento que se rebela contra a sua historicização, apesar de ele mesmo querer pertencer à história do anarquismo espanhol. Espera o seu reconhecimento, sem se dar conta de que, uma vez que faça parte da história, estará definitivamente aprisionado ao seu passado e às suas circunstâncias. Seu modo de viver indica, surpreendentemente, o contrário. Percorrendo as ruas de Barcelona, sua memória procura espaços onde ela se aloja, se aconchega e se encontra. Pode parecer incrível, mas no dia seguinte ao do bate-papo no restaurante, encontrei-me com Diego, nas proximidades do bairro gótico de Barcelona. Foi um encontro surpreendente, sequer poderia imaginar que seria levado por ele aos lugares onde as memórias do anarquismo se cruzam e se confrontam. Percorríamos as ruas do bairro gótico e Diego ia me dando toda a sua maneira de olhar aquela arquitetura a partir de sua própria história. Contava-me que, até o início deste século, o bairro era habitado pela aristocracia comerciante e industrial de Barcelona, uma fortaleza que era fechada no início da noite, para que os trabalhadores não perturbassem os prazeres e o descanso daquelas elites. Com o tempo, o bairro gótico se transformou, as elites abandonaram suas habitações e aos poucos o local foi se tornando um bairro boêmio, onde, à noite, os ideais revolucionários se combinavam com os prazeres da música, do sexo e da bebida. Andando pelas estreitas vielas, Diego me mostrou uma edificação que serviu de inspiração a Pablo Picasso quando este quis retratar o mundo da prostituição de Barcelona.

Enquanto andávamos pelas vielas do bairro gótico, Diego me convidou para conhecer um lugar muito especial que ele chamava de Chim-Pom. Alternava este nome com outro, Noche y Dia, que dizia ser inspirado na canção de Cole Porter, Night and Day. Caminhamos alguns minutos mais e de repente Diego apontou-me uma taverna com uma placa escrita Noche y Dia. Entramos e, em seguida, disselhe que eu tinha ouvido também algo como Chim-Pom e ele me confirmou. Afinal, Chim-Pom era o nome dado pelos anarquistas para tabernas onde eles iam discutir suas idéias e dançar ao som de boa música. Chim era o som do prato da bateria e Pom o som do contrabaixo. Tudo estava esclarecido, muito simples, não?

Acontecia ali um encontro anarquista regado de bom vinho espanhol. Discutiam ao mesmo tempo idéias libertárias e os rumos da vida de cada um. Pareceume que eles haviam se encontrado para homenagear Heleno Saña, um escritor anarquista catalão que tinha alcançado sucesso editorial na Alemanha, morando naquele momento em Hamburgo. Ficamos aproximadamente uma hora no Chim-Pom e aproveitei a oportunidade para gravar uma conversa muito engraçada de anarquistas. O dono da taberna, Juan Murilo, que servia o vinho com sua esposa Maria, uma senhora muito afável, em uma determinada altura da conversa, disse-me com muita convicção que a inteligência havia se retirado do mundo e que, hoje, ela pertencia a uma sociedade secreta. Julguei fascinante a sua afirmação. Desde minha chegada à 
exposição internacional eu também formulara esta idéia, com uma diferença: para mim o anarquismo transformara-se em um grupo seleto de pessoas que de tempos em tempos combinava um lugar no mundo para se encontrar, discutir idéias e reatualizar a memória.

Nos últimos anos eles haviam se reunido em Amsterdã, na PUC de São Paulo e, por último, em Barcelona. Desde o evento de São Paulo, eu havia tido esta idéia. Pela primeira vez me dei conta de que um lugar de memória poderia ser extremamente móvel, ao contrário do que poderia imaginar o historiador Pierre Nora. Havia, inclusive, a percepção de um ponto de fuga, onde o evento acontecia, seguido de uma dispersão. Tive na ocasião a percepção de que o evento não se historicizava, escapava, sorrateiramente, na dimensão do inefável. Os lugares imóveis de memória foram levados em consideração, tanto São Paulo, como Barcelona. Discutiu-se com muita atenção o problema da organização dos arquivos da memória anarquista. Contudo, os membros desta sociedade secreta apareciam com muita espontaneidade perante o público interessado em participar das discussões sobre as idéias anarquistas, sem deixarem transparecer o pacto da memória criado, sem muitas regras formais entre eles. Eles se conhecem, se encontram, trocam idéias mas, para olhares estranhos, não se percebe que esta memória coletiva reserva uma autonomia, sem precedentes, para a memória individual. Eles não se utilizam do evento, por eles criado, para realizar um ritual de memória institucionalizada. Ao contrário das comemorações oficiais, a memória neste grupo de anarquistas fica livre e sem fronteiras, libertando o evento, sem que eles percebam, das amarras da historicização.

Eles não são um grupo homogêneo. Existem sócios remidos, porque antigos, e outros sócios antigos, mas nem tanto, que vivem a fustigar pontos conflitantes da memória dos mais velhos. Em torno deles, um grupo jovem indefinível, ocasional, que aparece sempre quando se tem notícia de um encontro destes anarquistas. Entretanto, mergulhando na memória do anarquismo, podemos entender um pouco as dimensões do imaginário dos eventos realizados.

Em Barcelona, eu procurei uma explicação minimamente plausível. Devo reconhecer que estas pistas me foram dadas pelo próprio Diego Camacho, que ainda me reservaria outras surpresas. O quadro que ele apresentou me pareceu extremamente sugestivo. De acordo com seu ponto de vista, seria possível identificar três tendências no anarquismo, tomando como referência a experiência espanhola. Uma tendência camponesa, que floresceu nos campos andaluzes, provavelmente, definida por Eric Hobsbawm como rebeldia primitiva, pré-política, resistente aos processos de modernização capitalista ocorridos na propriedade agrícola. Um anarquismo de hordas rebeldes, extremamente agressivas, muito pouco afeitas às formas modernas de organização política. Uma tendência sindicalista que floresceu nas regiões industriais da Catalunha, tendo uma atividade política agressiva de ação direta 
voltada à classe operária, profundamente avessa às formas de participação e ação políticas desenvolvidas pelos partidos socialistas e trabalhistas nos limites dos Estados nacionais. Por último, uma tendência que ganhou simpatizantes, principalmente, na região madrilenha, onde predominava uma indústria de tipo artesanal. Ali, uma organização de trabalho que valorizava a autonomia do trabalhador propiciou o desenvolvimento de uma corrente libertária marcadamente individualista e intelectual.

Este modelo de interpretação me foi extremamente útil para diferenciar os grupos participantes da exposição internacional. A rebeldia camponesa estava significativamente representada em Barcelona pelos grupos alternativos punks, novas hordas que surgiram na crise da modernidade, com o desemprego e a recessão mundiais. Com suas roupas exóticas, amantes inveterados da raiz contestadora do rock, eles circulavam descontraidamente pelos espaços da exposição. Ao lado deles, encontravam-se os sindicalistas revolucionários, herdeiros da tradição de luta da Confederação Nacional do Trabalho (CNT) espanhola, que conquistou um lugar inamovível na história do anarquismo por ocasião da Guerra Civil. Esta tendência do anarquismo vive, hoje, a crise de legitimidade e de identidade que se manifesta em todas as tendências sindicais de inspiração socialista. Sindicalismo de resultados, reformista ou sindicalismo combativo e revolucionário? Questão que ficou sem resposta satisfatória depois de várias discussões realizadas durante a exposição internacional. Presente também a vertente classista do movimento anarquista, vivendo, hoje em dia, as agruras da crise que se espraia nos meios sindicais. Por último, a vertente intelectual, uma geração, quase em sua totalidade, ligada aos meios universitários, representante do livre pensamento e do individualismo libertário. Eles representam, aos olhos dos outros grupos, com certa dose de desconfiança, os elementos capazes de revalorizar as idéias anarquistas, num momento de crise das utopias da modernidade.

Percebo que o imaginário anarquista se move entre estas tendências, apesar da existência de outras correntes, principalmente a feminista, muito agressiva e combativa, marcando uma posição significativa durante todos os dias de debates da exposição internacional. As Mujeres livres de Barcelona e outras representantes do movimento feminista abrem as portas do anarquismo, denunciando os seus desvios machistas, sua falta de atenção às formas de opressão vividas pelo universo das mulheres. Um discurso da diferença em um congresso que visava delinear a identidade do militante do anarquismo. Um contra-discurso incômodo e combativo, que não se inibiu diante de algumas vaias e protestos daqueles que pretendiam silenciar as vozes das mulheres.

Mesmo levando-se em conta estes novos posicionamentos, o imaginário anar118 quista me pareceu oscilando em torno daquelas três tendências que me foram 
sugeridas pela aguda percepção de Diego Camacho, antigo anarco-sindicalista, hoje um livre pensador libertário. Esta tipologia, apesar de um tanto genérica, me foi útil para o meu movimento durante toda a exposição internacional. Embora não completamente convencido da pertinência dessa divisão tríplice, ela me ajudou a discernir tendências e conflitos, algumas vezes dissimulados durante as longas exposições e discussões. Esta mania do historiador e de outros cientistas sociais de classificar e tipificar as experiências sociais, compôs, em certa medida, o meu modo de observação do evento. Este tributo eu, realmente, reconheço que tenho a pagar. Ele, com certeza, facilitará a compreensão de meus eventuais leitores apegados à explicação histórica ou sociológica do real. Afinal, recorrer à análise do real, continua sendo a melhor maneira de aprisionar os eventos nos limites de sua historicidade.

Diego Camacho, com sua criativa tipologia, havia me dado elementos para que eu pudesse realizar meu trabalho durante a exposição internacional. Nos seus aspectos rituais, a exposição parecia confirmar a análise de Diego. Nos primeiros dias, mesas redondas onde os intelectuais acadêmicos do anarquismo, reconhecidos no cenário universitário, repensavam a doutrina sob o prisma dos impasses vividos pela modernidade. Daí em diante, as outras vozes puderam se manifestar. Os anarco-sindicalistas expuseram as dificuldades vividas junto ao operariado industrial; também grupos alternativos encontraram o seu espaço. Estando na exposição, não como um militante, mas como alguém interessado em estudar o anarquismo, fui alocado pelos organizadores nas sessões dos grupos alternativos, com os quais, aliás, eu, como estudioso, mais me identificava.

O leitor deve ter notado que, por eu ter uma chave para desvendar o real, ele tornou-se perfeitamente racional. Aliás, a própria organização da exposição procurou respeitar esta tipologia consagrada pelo tempo histórico. Este é o verdadeiro problema, nós nos movemos em várias dimensões do tempo, sendo que a mais convencional de todas é aquela, consensualmente consagrada, do tempo histórico.

Contudo, o que acontecia de mais interessante eram as conversas e encontros com militantes anarquistas de todas os partes do mundo. Alguns deles são personagens que sustentaram e sustentam até hoje a tradição anarquista. às vezes são pessoas mais familiares a nós, como Jaime Cuberos, do Centro de Memória Sindical de São Paulo, esta personagem fascinante que faz com que os eventos do anarquismo se atualizem em cada um de nossos encontros em São Paulo. Aliás, devo admitir que foi o Jaime Cuberos quem me deu, involuntariamente, a idéia de estudar a memória do anarquismo. Tenho esta dívida com ele. Sua memória prodigiosa me colocou diante de um mundo de eventos completamente desconhecidos por mim e que, no entanto, marcam a memória da cidade de São Paulo. Eu não vou me alongar muito com a presença de Jaime porque ele faz parte de um outro trabalho meu com a memória, que está em gestação. 
Pois bem, como eu estava dizendo, observando a circulação das pessoas, me dei conta de que eu percebia que o anarquismo passava realmente para o campo das tradições. Aliás, convivendo por mais de dez dias com eles, eu me convenci que assim ele deve permanecer, quase como uma sociedade internacional secreta, que de vez em quando dá as caras em encontros internacionais. Nos intervalos entre os encontros, a idéia anarquista vai se disseminando em todos os campos do pensamento, até o momento em que as pessoas se descobrem anarquistas e, então sim, procuram localizar essa singular sociedade secreta. Ela, inclusive, tem pouquíssimos rituais de ingresso, mesmo porque as pessoas já pertencentes a ela nem sabem da existência de tal sociedade. Eu espero que você, leitor, não leve na ironia o que eu estou dizendo. Quantos saberes de nosso mundo continuam num terreno hermético e despertam a nossa curiosidade, justamente, por serem quase inacessíveis?

Do meu ponto de vista, os velhos militantes têm uma importância decisiva na existência do grupo. Por isso mesmo, a força da tradição é muito grande. Por outro lado, sentimos em todos os momentos da exposição uma visível quebra de tradições entre as velhas e as novas gerações do anarquismo. De fato, quando os detentores da memória libertária não existirem mais, o destino desta comunidade estará, provavelmente, ameaçado. Neles o tempo faz dobras, possibilitando que os eventos se alarguem e se espraiem. Neles, a história se transforma numa ficção coletiva, porque os eventos vividos por eles se libertam das cadeias do tempo histórico. Neles, os eventos já estão incorporados ao tempo mítico.

Eu havia conhecido Lucce Fabri na PUC de São Paulo, uma libertária simplesmente fascinante. Ela, talvez, seja a mais importante personagem feminina do anarquismo ainda viva. Com seus 84 anos de idade, ela nos dá a dimensão de que a memória só é incomensurável quando se trata de alguém que teve uma experiência muito rica de vida. Uma vida sem experiências é uma vida sem memória. Com Lucce, damo-nos conta de que a experiência da vida é fundamental para a constituição dos quadros da memória. Em personagens como Lucce, a memória pode ser reconhecida em toda a sua dimensão, está para além da história, libertou-se das amarras do tempo, autonomizou-se. Este o momento supremo da memória encarnada nesta libertária. A insustentável leveza da memória arrasta Lucce para as correntes desta ficção coletiva que é o anarquismo. De que tempo estamos tratando, ao ouvirmos Lucce dizer que, quando pequena, brincava debaixo da mesa, enquanto seu pai, este personagem importante do anarquismo italiano, Luiggi Fabri, mantinha um acalorado bate-papo com Malatesta? Contou-me que, algumas vezes, o próprio Malatesta interrompia as conversas para dar mais atenção a ela. Para a história isto representa apenas um evento a mais na vida desta libertária. Para a memória, um convite a uma viagem mágica aos lugares onde viveram estas figuras 
míticas do anarquismo. Ouvir Lucce é, antes de tudo, deixar-se levar pelas correntes da memória coletiva libertária.

Para mim, se a memória é uma deusa, Mnemosine, no anarquismo ela está, hoje, representada por Lucce Fabri. Acredito ser possível avançar nos estudos do anarquismo se levarmos em consideração o aspecto mítico de sua memória. A figura de Lucce Fabri - uma mulher, da mesma forma que a deusa da memória - já fornece, para nós historiadores, uma boa pista.

Começamos a perceber que o anarquismo é uma doutrina da memória. Operando através de imagens, ele cria as analogias entre elas, possibilitando o exercício da mnemônica, tão decisivo para a preservação das tradições coletivas. Ao contrário do marxismo, que se desenvolve pela elaboração abstrata dos conceitos, o anarquismo é imagético, pertence ao campo das tradições orais e populares e, portanto, está imerso no campo do imaginário coletivo. Não é sem motivos que um importante livro sobre o anarquismo espanhol faz menção em seu título à figura de uma mulher, La musa libertária, uma deusa da memória que nos conduz para as fronteiras do impossível, do inatingível, este lugar onde não tem mais valor algum o tempo da história.

Lucce e Diego me colocaram diante de uma dimensão que eu ainda não tinha me dado conta. Já havia trabalhado a questão da memória em meu livro 1930 - O silêncio dos vencidos, procurando mostrar como somente a memória do vencedor se institui enquanto memória histórica e como determinados agentes históricos permanecem no silêncio, ou aparecem sob um manto de cumplicidade com o vencedor. Não havia me dado conta deste lugar onde a memória se desprende da história, se autonomiza, se embaralha e se confunde com aquela história vivida como uma ficção coletiva, ganhando uma dimensão mítica, onde os deuses são encarnados em figuras marcadas por uma experiência singular.

São eles, Diego e Lucce, lugares móveis da memória. Por isso, conhecê-los é também tomar contato com este lugar da contra-história - ou da história a contrapelo, como chamou Benjamin - este ponto muito tênue e impreciso, onde o tempo histórico faz uma dobra para deixar aparecer o inatingível da memória. Este lugar onde o passado e suas permanências passam a visar o futuro, porque o presente carrega consigo todas as esperanças de uma memória ainda não realizada, frágil, muito ligada à oralidade e à experiência do vivido mas que, ao mesmo tempo, ocasiona em nós a retenção de imagens indeléveis. Nas muitas horas que passei com Diego e Lucce, acabei por sentir-me, eu também, arrebatado pela idéia de que, em meus 48 anos, os registros do meu passado não devem ser um obstáculo para a vida. Não é preciso ser como Funes, o Memorioso, de Borges, que abre mão de seu direito de viver, por permanecer aprisionado às lembranças. Ao contrário, a experiência 
com estas deve permitir que nos reconciliemos com o passado, para fazer com que o viver do novo não pisoteie aqueles que estiveram conosco nesta grande aventura que é a própria vida.

Diego me deu esta dimensão incomensurável da memória. Depois de conhecê-lo, combinamos uma entrevista na residência de Diego, onde estaria presente também, Rudolf de Jong, já apresentado. Ao chegarmos no apartamento, no bairro de Gracias, onde o espaço era dividido com jovens italianos completamente despojados, tive a sensação de entrar em uma comunidade anarquista. Diego, com seus olhos e comentários ria de toda a situação. Dizia, sem qualquer sarcasmo, que naqueles dias, ele preferia permanecer nos bares, até tarde, pois os hóspedes tiravamlhe o espaço de privacidade. $\mathrm{O}$ ambiente de seu apartamento, desde o início, era desconcertante. Mas, Diego parecia não se incomodar. Logo no início de nossa conversa, ele me perguntou, novamente, como eu tinha chegado até ele. Repeti que havia recebido indicações de uma professora da Universidade Livre de Barcelona, Verena, é claro.

Sem rodeios, Diego quis saber se eu tinha lido algum de seus livros, porque eu me apresentei como um pesquisador interessado no anarquismo. Disse-lhe, sinceramente, que não. Ele continuou: "Jamás has leído Durruti, el proletariado en armas?" Desconcertado lhe respondi que sim, e observei que, segundo minhas referências, este livro era de autoria de Abel Paz. Diego sorriu e disse-me que Abel Paz tinha escrito boa parte das memórias dele, Diego. Fiquei muito confuso, afinal com quem eu estava falando? Eu, de fato, havia lido o livro de Abel Paz, que é uma referência fundamental para os estudiosos do anarquismo e da Guerra Civil Espanhola. Estava eu diante do próprio autor? Presumivelmente, sim. Disse-lhe que conhecia o livro de Abel Paz e Diego, em seguida, com um olhar ainda mais intrigante, perguntou-me se eu não gostaria de ler os outros livros publicados pelo mesmo autor. Tratavam todos eles de relatos de memórias. Em seguida, deu-me um outro livro de Abel Paz, Alpie del muro, que tem um prólogo simplesmente impactante. Segundo este autor, surge em sua vida uma personagem vinda das sombras, denominada Ricardo Santiny, que trazia um manuscrito em suas mãos. Desejava que o manuscrito fosse publicado com um prefácio de Abel Paz, autor já conhecido pelo público catalão. Abel Paz descreve Ricardo como uma imagem de si próprio. É impressionante o que diz Rodrigo a Abel Paz: "Mientras alentemos, nuestra misión es de remover el tiempo para impedir que el tiempo muerto entierre el tiempo vivo del espíritu $y$ de la idea".

Diego, encontrando-se com as várias personagens de sua memória, só pode parar diante de si mesmo, perplexo diante da própria dimensão polimorfa de sua personalidade. Diante de tal situação, reflete: 
- Al final llegué a entender bien lo que mi amigo me pedía confiándome su escrito. Y lo que me pedía no era otra cosa que yo asumiera su paternidad: Y no solamente por mediación del prólogo sino amparando con mi nombre su obra. ¿Y, como se puede negar a un segundo yo una demanda como esta? Al fin y al cabo yo podia suscribir cuanto él habia escrito, porque era mi propia historia. Esa es la razón por la que prologuista y autor del libro confunden bajo un solo nombre.

A personagem que está diante de mim faz um jogo completamente indecifrável com a memória. Diante de quem eu estou? Julgo-me incapaz de definir qualquer figura que se assemelhe à identidade. Tenho que admitir que o tempo produz desdobramentos na memória e que estou diante de uma personagem cuja experiência de vida esteve sempre nas dobras do tempo. Existe Diego, assim como existe Ricardo Santiny. Um e outro viveram, no fundo de suas existências, os caminhos trágicos da Guerra Civil, relatados de forma pungente na escrita de Abel Paz. Que também é uma personagem, que viveu durante muitos anos no exílio na França. Eu não tenho a menor dúvida que Abel Paz estava vivendo na França durante a ditadura de Franco. Hans Magnus Ensensberger, no prefácio de seu magnífico livro sobre Durruti, agradece afetuosamente a Abel Paz por suas valiosas informações, como participante da coluna de Durruti. O poeta alemão, na época em que se envolveu com o anarquismo espanhol, conheceu este escritor sensível, cujo nome é Abel Paz.

Eu, ao contrário, conheci Diego Camacho. Ele deve ter usado esta dupla personalidade durante o exílio na França. Mas o poeta alemão não estava interessado nisso. Uma pena, porque perdeu uma excelente oportunidade, pois Diego, isto é, Abel Paz, pertencem à memória coletiva. Decifrá-los faz parte do enigma de nossa poesia, mesmo que tenhamos de enfrentá-los numa linguagem de prosa. Diego, Abel Paz, ou Ricardo Santiny, todos eles me acompanhavam pelas ruas de Barcelona. Cada um deles tendo vivido experiências diferentes de vida, marcadas pelo exílio, pelos campos de concentração e por estas ruas estreitas e intrigantes do bairro gótico de Barcelona, onde eu e Diego (?), caminhávamos, com suas lembranças das jornadas memoráveis do proletariado em armas engajado nas fileiras da coluna Durruti.

Diego me parece mais livre do que as outras personagens de sua vida, difíceis de serem decifradas. Ele é um libertário, após muitos anos de militância anarquista. Não quer ser em vida as memórias do exílio e do campo de concentração. Contudo, não quer negá-las, e Abel Paz cuida disso ciosamente. Tenho a sensação de que Diego não quer ser o herdeiro direto destas tradições do anarquismo. Ele as deixou a Abel Paz, que tem a responsabilidade de fazê-las vivas, renová-las no fluxo incontrolável da memória coletiva, fazer com que elas não se percam no esquecimento, este inexorável destino de todas as memórias orais. Por isso, Abel Paz regis- 
tra sua memória em uma escrita, talhada para ser um documento permanente de todos os confrontos que o anarquismo viveu, para não se deixar transformar em um dos Vestígios do dia, clara citação deste magnífico filme de James Ivory. Sair da sombra, não ser vestígio da luz. Eu acho que esta é a dimensão inexorável da memória desta figura incrível que é Abel Paz e que poderia ser estendida, também, a Lucce Fabri. Não ser um resquício de luz que sobrevive ao fim de cada dia. Eles têm o sentido da permanência, dão-nos a dimensão da autonomia da memória, oferecem-nos este lugar onde ela se revela na dobra da história, como contra-história, como fugaz momento que escapa de nossas mãos. Cabe a nós perseguir este movimento maleável da memória ou não? Que sé yo?

Assim como as personagens que habitam o Olimpo eles são em parte deuses, em parte seres humanos. Alguém pode perguntar: o Edgar está querendo transformá-los em mitos? Sim e não. Eu me proponho, pelo menos durante uma fração deste tempo tão racional, a admiti-los fora de suas historicidades específicas. Diego e Lucce nos dão esta dimensão do indecifrável. No convívio com eles, temos a sensação de dialogar com pessoas comuns, muito vividas, por outra parte. Contudo, as coisas se transformam ao ouvirmos suas vozes, trazendo imagens muito atualizadas de um passado que em suas memórias liberta-se da historicidade, como querendo nos transmitir a dimensão não comensurável da experiência do vivido. Esta reposição dos eventos transfigurados em imagens indomáveis, irrequietas e reatualizadas por uma memória que se expõe a nós por saltos, interrupções, desvios, equívocos, parece seguir o imenso caudal de uma ficção coletiva. Esta é a dimensão pela qual o passado não se torna estranho a nós, não o vemos com o sentido da alteridade, de um vivido por um outro dessemelhante, mas torna-se identificável conosco, porque em outro momento, outros seres humanos lutaram pelos mesmos ideais por que, ainda hoje, estamos nos empenhando.

$\mathrm{Na}$ memória, os eventos parecem movimentar-se por um efeito bumerangue. Lutas perdidas, ilusões abortadas parecem adquirir uma força maior quando entrelaçadas no fluxo de esperanças coletivas. Elas retornam com uma força inesperada, como se a memória não se deixasse adormecer na tranqüilidade de um passado não realizado e ainda não redimido. Presentificar o passado passa a significar a reatualização na memória de alguma coisa que poderia ter sido, mas não foi.

Não será a História que poderá redimir esse passado, porque ela o aprisiona nas cadeias do tempo linear. Assim como a história dos historiadores exige credenciais para qualquer um que queira participar de suas seqüelas e controvérsias, a memória também reivindica uma predisposição, um abrir mão do primado incômodo da historicidade. Ali onde o historicizar deixa de ser uma necessidade urgente, a memória flutua, deixando os eventos se espraiarem, permitindo que eles se soltem das amarras do tempo cronológico. Os fatos de agora são vividos sempre como si- 
tuação de urgência, e deixam-nos a sensação de que o tempo do vivido é mais maleável do que a gente possa imaginar. A memória nos pega sempre de surpresa, entra sorrateira nos escaninhos do tempo cronológico, sempre fugidia, maleável e fugaz.

Não posso deixar de reconhecer que esta dimensão da memória, presente nas correntes do anarquismo, me deixou desconcertado. Após cada dia vivido em Barcelona, corria atrás de meu diário e transcrevia compulsivamente o meu desconcerto. Perguntava a mim mesmo: aonde isto tudo irá me levar? Debatia-me com as hipóteses de meu trabalho, com elas mesmas, que tornaram viável meu plano de pesquisa. Eu havia traçado um mapa a partir de pressupostos teóricos e historiográficos para os quais, mal ou bem, eu esperava encontrar algumas respostas, durante a realização deste evento internacional do anarquismo. Foram estas as questões que me deixaram desconcertado. Qual é o lugar mais apropriado para entender o movimento maleável, instigante e insinuante da memória anarquista?

Em meu projeto de pesquisa eu havia considerado a possibilidade de entender a permanência e a propagação das idéias anarquistas a partir da ação direta, que, por sua vez, pressupõe a autonomia e a liberdade do indivíduo guiado, única e exclusivamente, por sua consciência. Liberdade pública capaz de criar um espaço político alternativo ao espaço político burguês. Uma outra esfera de sociabilidade não hierárquica, diferente daquela concebida pelos princípios liberais, onde a esfera pública acaba por estabelecer uma harmonia fundada na desigualdade. Em meu plano de pesquisa procurava encontrar o espaço de uma comunicação entre indivíduos, horizontal e não hierarquizada, capaz de autorizar uma crítica aos pressupostos da doutrina liberal e também de correntes de pensamento indisfarçavelmente mais autoritárias, que sempre advogaram a autoridade do Estado, como árbitro inconteste dos conflitos vividos pelo social.

Para os meus pressupostos, a doutrina anarquista necessitava da ampliação do espaço público para se espraiar e se efetivar como domínio da consciência autônoma e individual. Isto é, considerava a experiência de um viver livre e autônomo, como premissa fundamental para constituição de uma memória coletiva de cunho libertário. Mas, a minha vivência, durante dias, mergulhado entre os anarquistas, me desvendava um outro universo, não menos impactante. Algo me sugeria que os fluxos da memória coletiva caminhavam, conflitantemente juntos, com a instituição de um espaço público novo e alternativo. Afinal, ninguém poderia propor, em sã consciência, organizar uma exposição internacional sem ter em mente a possibilidade de divulgar, publicamente, as idéias e possibilidades de uma doutrina tão relegada ao silêncio e tão desautorizada, como tem sido, ao longo do tempo histórico, a doutrina anarquista.

A exposição internacional do anarquismo se constituía como uma possibilidade para mostrar às autoridades do saber historiográfico, que o anarquismo não 
estava aprisionado ao tempo de sua enunciação. Na maioria das vezes, os historiadores de profissão - e cito, como exemplo, um de seus nomes mais famosos, Eric Hobsbawm - aprisionaram o anarquismo em um tempo histórico no qual ainda predominava um modo comunitário e, por que não dizer, prosaico de vida. Isto é, aderir ao anarquismo seria como viver uma experiência de vida na contracorrente do relógio da história. Ele, na história, teve o seu tempo e, por isso, assim como muitas outras experiências, seus ideais e promessas deveriam ter o seu lugar assegurado, como tantas outras formas de pensamento, na corrente inexorável do tempo histórico. Seu modo de conceber as possibilidades de um viver livre, não autoritário, anti-hierárquico deveria estar racionalmente resolvido por um pertencimento ao passado. Diante das prerrogativas de uma exigência racional da política moderna, precisamos saber como nos desvencilhar deste pensamento que, assim como tantos outros, continuam a fustigar a nossa imaginação e nossas esperanças.

Entretanto, à revelia de historiadores do porte de Hobsbawm, o anarquismo insiste em permanecer como um repertório de idéias capazes de orientar as nossas opções para o devir histórico. A historicidade não é capaz de silenciar e impedir o retorno das idéias que possibilitam, ao preço de muita insistência, o reviver das utopias libertárias. Algumas vezes, me perguntava, durante aqueles dias em Barcelona: historicizar, infelizmente, é preciso? Mas, ainda bem que viver não é preciso. Não podemos, jamais, medir a inusitada dimensão da experiência de nossa própria vida. Esta é a dimensão incomensurável da memória. Por mais que queiramos aprisionála, ela nos escapa. Reatualiza-se num mundo marcado pela efemeridade, isto é, pelo efêmero, pelo evanescente, deixando sua marca, abrindo os horizontes para percebermos a insurgência do evento diante das insistências de sua historicização.

Vou me dando conta, aos poucos, de que os vencedores agem com uma tática muito inteligente. Fazem com que a memória dos vencidos fique aprisionada ao tempo histórico, como querendo dizer, por exemplo: o anarquismo teve o seu momento, mobilizou consciências, mas já passou a sua oportunidade histórica. Mas que belo ardil. Pois não é que, ao mesmo tempo, os eventos do vencedor, como num passe de mágica, devem estar sempre superando o tempo histórico. Aconteceram, mas continuam a reverberar na invenção das tradições, nas comemorações oficiais e em seus rituais periódicos. Há sempre a reatualização de sua memória e a expropriação de outras que não se deixam aprisionar pelas armadilhas do tempo não histórico dos vencedores. Assim como os vencedores podem se dar ao luxo de escapar do tempo histórico, para melhor exercerem o controle do imaginário de seus opositores, eles acabam definindo, à sua própria revelia, o campo de luta por fora deste tempo histórico. Esta me parece ser a abertura mais instigante dos estudos atuais sobre as relações entre a memória e a história. 
As lutas pelo direito à memória devem-se mover num terreno muito pouco histórico, elas devem admitir o caráter ahistórico da memória dos vencedores. Por que somente os eventos dos vencidos devem ser submetidos à dura lei do tempo histórico, por que somente eles devem ser aprisionados e legados ao julgamento de uma época, período, etc., todas estas artimanhas usadas pelo discurso historiográfico? Os vencedores sempre determinam o sentido histórico dos eventos do outro e também, em nome de uma história que é tão somente a sua própria memória, legitimam as suas vitórias para melhor escaparem das armadilhas deste tempo cronológico aprisionante, que também os deixaria na incômoda posição de desidentificação com o passado. Esta operação ardilosa de identidade com o passado só é autorizada aos vencedores. $\mathrm{Na}$ perspectiva dos vencidos ela aparece sempre como um anacronismo. Já não somos mais tão ingênuos para cair nesta armadilha. Qual é? Nós já matamos esta charada! As próximas lutas serão travadas por fora do tempo histórico, podes crer!

O próprio conhecimento histórico já descobriu as chaves deste mistério que está alojado no campo da memória. Um exemplo clássico pode ser citado. Querem ver? Agnes Heller, em sua obra importantíssima, O homem do Renascimento, ao invés de identificar visões conflitantes de mundo na estruturação do pensamento europeu sobre o homem renascentista, resume e sintetiza o espírito de um período. Apesar deste descuido, ela percebe muito bem como, para aqueles que dominaram a cultura deste período, foi possível a identificação com um passado que não estava aprisionado nas correntes de um tempo histórico: O Renascimento foi a primeira era que escolheu um passado para si própria. Sartre viu corretamente nisto um critério de liberdade, pois constituía de fato um sinal de libertação dos vínculos da vida feudal ou comunitária. Os povos que ainda vivem dentro dos limites destas comunidades recebem o passado já feito e dado, sob a forma de mito. Podem transformar estes mitos ou reinterpretá-los, mas não podem escolher para si próprios um outro passado. Vocês percebem a força desta constatação?

Não estamos falando do universo dos mitos, indispensáveis para a sustentação das formas comunitárias de vida onde predomina a força da memória coletiva, transmitida através da oralidade. Heller nos desperta para um problema completamente novo, para a liberdade de invenção do passado, para a libertação do evento das cadeias do tempo histórico. Terá Agnes Heller se dado conta, como boa marxista que é, de que afirmou que a autonomia e a liberdade do homem moderno estão marcadas por sua capacidade de desamarrar os eventos das cadeias do tempo histórico!? Ainda bem que não estamos sozinhos nesta viagem transoceânica a Barcelona, em busca da memória do anarquismo. Outros já procuraram fazer esta mesma travessia no tempo, embora com diferentes motivos, mas talvez coincidentes 
com os nossos próprios motivos, num outro nivel de vínculo. Devemos estar muito atentos quando falarmos nisso de invenção das tradições, pois estaremos diante de situações em que o evento quer, abertamente, libertar-se da história. Todo o evento que se reatualiza na memória coletiva já indica, por si mesmo, uma indisfarçável intenção de ultrapassar as barreiras rígidas da cronologia.

Poderíamos sugerir, então, que a experiência da memória caminha pelo menos em duas dimensões. A primeira, onde a memória se estrutura para dominar o passado, isto é, torna-se experiência individual e coletiva que busca o domínio do tempo. Desta conformação da memória para abarcar o tempo e o passado individual e coletivo, nasce provavelmente a história. A partir dessa dimensão da memória desenvolve-se um saber que tem como objeto de interpretação os eventos humanos submetidos a uma historicidade. A outra dimensão da memória, individual ou coletiva, torna-se uma experiência de libertação em relação ao tempo. Entrar nesse mundo significa, principalmente, escapar da armadura temporal que distingue cronologicamente o passado, o presente e o futuro. Nessa dimensão as relações da memória com estes tempos são completamente relativísticas, para usar uma terminologia da física de Einstein.

Posso fazer - e por que não? - a seguinte suposição: se a memória individual ou coletiva contém todo o passado, é porque somos, enquanto indivíduos, um lugar de cruzamento. Atravessam em nós correntes de memória e nessa medida nós somos suportes de todo o passado. Cada um de nós organiza a memória de infinitas formas e, por isso mesmo, temos a sensação de existirmos enquanto individualidades diferentes. A memória como suporte do passado produz a individualização, marcando a diferença entre o eu e o outro e faz com que cada um realize a sua travessia no tempo através da ação. A memória enquanto suporte do passado joga-nos para uma ação no futuro, que em sua efetivação torna-se presente, que é por excelência o império do efêmero.

Assim, a memória só nos faz buscar mais passado, pois cada ação projetada para o futuro que se presentifica nos põe em contato com outros indivíduos que, por sua vez, são cruzamentos de outras infinitas memórias. Se aceita esta hipótese, conhecer um(a) outro(a) é estar entrando no túnel da memória, pois ele(a) nos trará de uma outra maneira todo o passado. Nesse sentido, nossas vidas não caminham para o futuro, ao contrário, este futuro como ação não realizada, está esperando apenas a sua efetivação e desde logo torna-se o lugar de alargamento de nossas fronteiras em direção ao passado. Assim, torna-se possível imaginar que o tempo corre para trás e não para a frente. Este é, do meu ponto de vista, o caminho mais fértil para se trabalhar com a memória, isto é, subvertendo a estrutura do tempo histórico, cronológico e linear que marca de um modo sucessivo o passado, o presente e o futuro. Somente por meio desta organização se torna possível definir o 
tempo histórico como tempo do progresso, onde os eventos estão aprisionados na lógica das causas e dos efeitos. Nada disso funciona no tempo da memória, ele nos conduz, a cada uma de nossas ações, em direção ao passado, pois me comunicar com um(a) outro(a) significa mergulhar na corrente de uma outra memória, descobrir neste(a) outro(a) novas experiências com o passado.

Viver é, portanto, alargar as fronteiras do passado, é expandir o campo da memória individual através de cruzamentos infinitos com outras memórias que vão nos agregando experiências de vida, saberes, afetividades, promessas e também desilusões. Enfim, a única coisa que podemos reter do(a) outro(a) são as suas memórias. Elas, sim, nos impregnam ao longo da vida, até ao ponto em que submergem nas águas do esquecimento. Utilizando uma teoria da física, poderíamos dizer que existem buracos negros da memória. Eles parecem sugar com uma força inexorável o fluxo de nossas lembranças, dando-nos a sensação de que existem lapsos e falhas na memória. O esquecimento significa perda da capacidade de atualização de algum evento na memória, sua recuperação parece impossível, ainda que possam sobrar alguns traços muito tênues de sua existência.

Aliás, já que estamos fazendo um exercício de compreensão do funcionamento da memória, poderíamos sugerir um outro paradoxo. Comecei este ensaio descrevendo minha viagem em direção a Barcelona. Do ponto de vista de um tempo cronológico que passa, eu estava viajando em direção ao futuro. Pois bem, partindo desta situação, poderíamos imaginar uma outra muito semelhante. Suponhamos duas pessoas que estão em cidades diferentes e que se telefonam para combinar um encontro. Na conversa, uma delas diz que partirá às seis horas da tarde e que, provavelmente, se encontrará com a outra pessoa por volta das oito horas da noite. $\mathrm{Na}$ memória da pessoa que viaja, a outra pessoa já está no futuro, isto é, ele existe antes que a primeira pessoa possa presentificá-lo. Para tornar o futuro presente esta pessoa tem que fazer uma viagem de duas horas, pelo menos. Nesse sentido, deste ponto de vista da memória, existe um futuro virtual que tem que ser efetivado como presente. Se deslocarmos o nosso referencial para a pessoa que espera a chegada da outra, a memória funciona de forma muito diferente. A outra pessoa que prometeu viajar às seis horas da tarde, vem do passado e deve percorrer em duas horas o tempo que a traz do passado para o presente.

Assim, dependendo do ponto em que estamos podemos ter o funcionamento da memória em direção a um futuro que tem que se efetivar como presente, ou então, sob outro referencial, esperamos que alguém chegue do passado para o presente. Não devemos tomar este problema como uma ilusão, mas sim como um efetivo funcionamento da memória nas redes do tempo social que instituem a seqüência passado, presente e futuro. A memória se amolda e se modifica, dependendo do referencial em que nos situamos, ela é maleável e suficientemente flexível para se 
acomodar de acordo com a variância de lugares. Por isso, os eventos na memória têm a sua atualização bastante diversa, dependendo do ponto onde estamos. Não há como repetir esta operação de atualização dos eventos da memória, sem que eles se modifiquem. Os eventos se atualizam sempre na memória, mas nunca como a mesma coisa. Há sempre a questão de que eles vêem na memória a partir de nossos referenciais. Por esta razão, os eventos da memória são indomáveis, eles irrompem num instante por uma concentração e depois podem se distender, até ao ponto de atravessarem outras redes de eventos. Isto é, depois de um instante de concentração, os eventos da memória reverberam e distendem-se, acabando por invadir o campo de outros eventos, modificando-os e atualizando-os.

Imaginemos por fim o encontro entre aquelas duas pessoas. As duas conseguiram efetivar um presente, só que de maneiras diferentes. Mas, enfim, elas se encontraram, para poderem viver juntas uma experiência com o passado, isto é, com a troca de referências das duas memórias. Viver junto com alguém significa tomar contato com as dimensões da memória de um(a) outro(a), aumentar a dois as fronteiras do passado.

Mas podemos deixar o campo destes paradoxos e voltar ao problema das relações entre memória e história. De acordo com a observação muito pertinente de Paul Veyne, o evento, para se tornar histórico, deve estar envolvido em uma intriga, numa rede que lhe concede pertinência e enreda-o numa historicidade. Na História, um evento nunca pode ser reconhecido individualmente, ele deve estar referido a uma intriga, a uma determinada narrativa que, por vizinhança, possa individualizálo, tornando-o, ao mesmo tempo, compreensível dentro de um determinado enredo. Neste procedimento historiográfico reconhece-se a natureza indomável do evento, mas por isso mesmo, torna-se necessário controlar as regras de seu movimento, envolvê-lo em uma trama, para que ele possa ser explicado. O conjunto dessas operações penosas constitui o que nós chamamos de historicização do evento. Um trabalho difícil de se realizar e estas são as qualidades de um historiador. Observar atentamente as vizinhanças do evento, dar-se conta de sua dispersão, controlar o seu enunciado, perseguindo, ao mesmo tempo, a sua migração para outra ordem de eventos. O historiador, hoje, deve estar atento à natureza dispersiva do evento, à sua descontinuidade, pois subitamente pode ser que se interrompa a sua reverberação. Nisto reside um dos momentos importantes do trabalho de compreensão histórica.

Não é uma falha do historiador a necessidade de controlar a dispersão do evento. Hoje, conhecemos as regras da pesquisa historiográfica e a maioria dos historiadores reconhecem a natureza rebelde do evento e as dificuldades de domá-lo no interior de uma intriga. Historicizar um evento é trabalho árduo de muita pesquisa para torná-lo compreensível em uma narrativa. Nós, que até agora contrapo- 
mos a memória com a História, devemos reconhecer também o esforço dos historiadores. No inventário das diferenças realizado pelos historiadores existe uma tentativa de relativizar os efeitos problemáticos da historicização do evento, quando buscamos suas reverberações, suas reatualizações e suas diferenças no movimento de repetição. Por isso, os historiadores usam o método comparativo em suas pesquisas, procurando assim controlar essas reverberações e dispersões, ao ponto de identificar as regularidades de efetivação dos eventos. Nesta perspectiva trabalham, hoje em dia, muitos historiadores, buscando criar novos conceitos e procedimentos metodológicos que possam apontar outras direções para o trabalho historiográfico. Temos como seguro que os eventos, ao serem controlados pela historicidade, podem se rebelar no interior da própria temporalidade que os envolve.

Esta é uma questão muito importante deixada pela pesquisa genealógica de Michel Foucault, ele nos alertou para a necessidade de estarmos atentos para os efeitos dispersivos dos eventos, para a sua descontinuidade e também para a sua regularidade. Devemos concordar que, nestas questões, torna-se difícil trabalhar com a categoria de tempo histórico, pois ela se autodefine como uma concepção de unidade e de totalidade temporais. Esta talvez seja a razão pela qual Foucault tanto elogiou a história dos Annales, por ela ter sido capaz de implodir a unidade do tempo histórico, propondo para a reflexão dos historiadores a existência múltipla de tempos do social, que não é marcada pela continuidade mas, ao contrário, induz-nos a pensar os efeitos da dispersão e da descontinuidade dos eventos e suas possibilidades de reverberação em várias dimensões temporais.

É interessante observarmos até que ponto a escola dos Annales reservou apenas para os eventos de longa e média duração os efeitos de permanência, ou se aqueles de curta duração também podem reverberar e se reatualizar. A geografia e o clima, a produção da vida material e os valores parecem ter efeitos de permanência, ao passo que os acontecimentos políticos, por exemplo, que muito fascinaram a história positivista événémentielle, também deveriam ser matéria de indagação para os historiadores dos Annales. Parece-me uma indagação pertinente, pois os eventos que irrompem no tempo de curta duração, isto é, no espaço temporal das conjunturas, não têm a possibilidade de ampla reverberação nas considerações desta escola de historiadores. Apenas nos últimos anos alguns destes resolveram enfrentar tal dilema na ordem dos tempos do social.

Pierre Nora, um importante historiador francês, preocupado com a questão da memória, procura tematizar as inflexões dos tempos sociais. Por isso, busca compreender como os eventos de curta duração acabam sendo levados por outras correntes de tempos sociais de média e longa duração. A partir destas questões, os historiadores atuais podem reconhecer, também, com muito respeito, as questões colocadas pelo livro $A$ memória vã, onde o autor defende a idéia de que um evento 
que teria sido abarcado pelo tempo histórico se rebela contra esse tempo, reatualizando-se e exigindo o direito de uma última aparição.

Para nós historiadores não é mais uma dificuldade, hoje em dia, entender esta interrogação do filósofo. A história pode dar conta também dessas inflexões e reverberações dos eventos em diversos tempos sociais, entendendo que eventos de curta duração podem se enredar nas profundas correntes dos tempos de média e longa duração e voltar a incomodar a nossa imaginação e a nossa ordem de valores. Assim, podemos entender a maneira pela qual o evento político do nazismo, tanto em sua aparição, como em sua condenação, tornou-se realidade por força de tempos médios e longos do social, que envolvem, principalmente, o campo dos valores elaborados por diferentes culturas. Ele, historicamente, pertence ao tempo da curta duração, segundo a escola dos Annales, mas a sua possibilidade de acontecer e de continuar reverberando está recoberta por outros tempos sociais, que vivenciamos como uma experiência muito pouco passível de ser domada por qualquer cronologia. Alguma dimensão de nossa mente parece-nos sussurrar que, na memória, os eventos escapam do tempo linear e cronológico e que nela este tempo deixa de ter efetividade ou, se quisermos, torna-se um tempo muito problemático. Na memória, a qualquer momento, um evento pode se reatualizar, pelo intrigante motivo de que nossas experiências de vida estão imersas em diferentes tempos sociais.

A nova história tem procurado enfrentar este problema colocado pelos estudos da memória. Autores como George Duby e Philippe Joutard estudaram de maneiras diferentes a dispersão dos eventos da memória coletiva. O primeiro, ao estudar a batalha de Bouvines como pista para entender o imaginário social de uma época, mas, ao mesmo tempo, buscando a reverberação deste evento na memória coletiva através de suas rememorações e comemorações. O segundo realiza um trabalho mais radical, onde encontramos uma maior afinidade com a pesquisa histórica.

O historiador Joutard, diferentemente de Duby, não corre atrás das representações mentais de um evento que o tempo histórico ajudou a sedimentar. Ao contrário, Joutard procura a irrupção de um evento que entrou nas correntes da memória coletiva e que, ao se libertar do tempo histórico, reverbera e sinaliza a sua atualização para um determinado grupo social. Como bem observou Jacques Le Goff à propósito da questão colocada por Joutard, os protestantes de Cevenne, depois das provas das guerras religiosas dos séculos XVI e XVII, reagem face à revolução de 1784, face à República, face ao caso Dreyfus, face às opções ideológicas de hoje, com a sua memória de camisardos, fiel e móvel, como toda a memória.

Estes novos posicionamentos dos historiadores não são outra coisa senão um despertar tardio para as relações que as memórias individual e coletiva estabelecem com os eventos em geral, sejam eles naturais ou humanos. Na verdade, concordando com as posições de Pierre Nora, a História se vê hoje pressionada pela irrupção 
das memórias coletivas que, num mundo de tremenda fragmentação, vêem a público exigir o seu direito de permanência, como demanda política de preservação de múltiplas identidades sociais. Estendendo estas pertinentes observações de Nora, diria que a memória coletiva acabou por inaugurar um novo campo de investigação para os historiadores, a história da História, uma nova reflexão e pesquisa para se saber como a História funciona e a quem ela serve ao longo de sua existência, como campo de saber sobre os eventos humanos.

Esta nova modalidade de estudo interroga o porquê da História historicizar e aprisionar no tempo determinados eventos, retirando-lhes a sua capacidade de ressurgimento, ao passo que ela constitui, paradoxalmente, através de suas pesquisas, novos lugares de memória, que estarão a serviço dos poderes do Estado e de outros meios políticos, transfigurados em sofisticados mecanismos de dominação. Esta nova frente de trabalho, isto é, fazer a história da História, nos permite avaliar as condições de historicização dos eventos como campo de luta, como o espaço de um embate tenso onde a historiografia tem de se defrontar com as correntes da memória coletiva.

Meu interesse pelo anarquismo surgiu, justamente, desta indagação. Como uma doutrina política da liberdade, o anarquismo, desde os seus enunciados, é rebelde a qualquer historicização, uma vez que sua memória instituiu a liberdade como bem universal, transcendendo as limitações do tempo histórico. Isto é, o ideal de uma humanidade livre e autônoma é trans-histórica, ainda que a história seja o lugar de realização dessa idéia. Em outras palavras, a história deve estar sujeita à intromissão de um outro tempo, o da memória coletiva, que será capaz de perceber a repercussão dos eventos humanos que apontem a criação de um espaço público, capaz de assegurar a autonomia e a liberdade, sejam elas individuais ou coletivas.

Por outro lado, interessei-me pelo anarquismo por ele se tornar, em todos os lugares onde aparece, uma irrupção da memória coletiva, que reatualiza os eventos definitivamente soterrados pelo tempo histórico. O anarquismo, no meu modo de entendê-lo, questiona a acertiva dos historiadores de que um evento não pode ocorrer por duas vezes. Lembram-se dela? João sem Terra não passa duas vezes pelo mesmo rio. Pela recusa em aceitar esta proposição, o anarquismo pertence ao campo da memória coletiva e não da história.

Ao contrário do marxismo, que se pretende ver realizado nas correntes do tempo histórico e que interpreta a reatualização do evento como farsa e tragédia, o anarquismo não se submete às determinações do tempo histórico, por perceber a potencialidade transformista dos eventos (não estou utilizando aqui a terminologia gramsciana, mas sim a do teatro vaudeville, dos gays, dos homossexuais, dos Dzi Croquetes, lembram-se deles?). A bem da verdade, Marx deve ter tido esta percepção quando interpretou os acontecimentos de 1848, na França. Ele se deu conta da re- 
verberação das jornadas revolucionárias de 1789, mas não deu o devido valor para a capacidade transformadora da memória. Viu nela, apenas, os aspectos de continuidade e permanência nostálgicas do passado. Não levou em consideração o fato de que um evento na memória só pode se apaziguar quando estiver devidamente redimido.

Foi nas relações tensas entre a memória e a história que procuramos levantar problemas e possibilidades de reflexão para o nosso ofício de historiador. Escolhi este caminho por julgar que o anarquismo convive com o conflito entre sua historicização e sua capacidade de escapar da história, reatualizando na memória coletiva dos grupos sociais eventos soterrados pelo tempo do passado. Ao contrário do marxismo, o anarquismo não quis validar a sua doutrina nas determinações do tempo histórico, quis escapar dele, instituindo na memória coletiva as idéias de liberdade e autonomia, como bens universais e trans-históricos. Por estas razões, creio que o anarquismo pertence não ao campo da história, mas sim ao da memória, que reconhece a rebeldia do evento em suas potencialidades de reverberação e dispersão. Em Barcelona, reatualizamos na nossa memória este evento indomável que é a vida vivida com autonomia e liberdade, no tempo propício de um encontro anarquista. A todos aqueles que lá estiveram presentes, dedico esta oração:

"E quando eu tiver saído para fora do teu círculo, tempo, tempo, tempo

não serei nem terás sido tempo, tempo, tempo.

Ainda assim acredito ser possível reunirmo-nos tempo, tempo, tempo, num outro nível de vínculo tempo, tempo, tempo."

(Oração ao tempo, Caetano Veloso) 